\title{
CEO Power and Auditor Choice
}

\section{Zenghui Liu}

Department of Accounting, Western Washington University, USA

\section{Bo Ouyang}

Management Division, Pennsylvania State University Great Valley, USA

\section{Xiaojie (Christine) Sun}

Department of Accounting, California State University San Marcos, USA

\begin{abstract}
In this paper, we examine the impact of CEO power on auditor choice. We are motivated by the competing financial reporting incentives arising from CEO power. Our empirical finding suggests that powerful CEOs are more likely to hire high-quality auditors as a signal of superior financial reporting quality. We contribute to the literature of auditor switch and extend the research on the links between CEO power and firm behaviors.
\end{abstract}

Key Words: CEO Power; Auditor Choice; Agency Problem; Corporate Governance; Audit Quality

JEL classification: G30; $G 39$

\section{Introduction}

We extend the research on the links between CEO power and firm behaviors by examining the impact of CEO power on auditor choice. Prior research on CEO power primarily focuses on the economic impact of CEO power, such as firm performance and firm valuation. There is no empirical evidence of how CEO power is related to specific managerial decisions. In this paper, we explore whether powerful CEOs are more likely to hire big-4 auditors.

According to conventional literature of corporate finance (Sydney Finkelstein, 1992), power is defined as "the capacity of individual actors to exert their will." and there are four sources of power: structural power, ownership 


\section{Z. Liu et al /International Journal of Finance \& Banking Studies \\ Vol 4, No 4, 2015 ISSN: 2147-4486}

power, expert power, and prestige power. Powerful CEOs thus can wield substantial influence over corporate decision makings through power embedded in the corporate hierarchy.

Prior research suggests that too much CEO power exacerbates agency problem as powerful CEOs tend to be overconfident and choose risky corporate strategies (Jeffrey Pfeffer, 2010). Bebchuk et al. (2011) provide empirical evidence that strong CEO power is also related to economic outcomes related to agency problems. Particularly, there are higher odds of the powerful CEOs receiving 'lucky' option grants and a higher tendency for powerful CEOs to be awarded for luck compensation in the form of positive industry-wide shocks. Bebchuk et al. (2011) also document that strong CEO power lead to lower firm value as measured by Tobin's q and subpar accounting performance. Furthermore, firms with powerful CEOs are more likely to conduct value-destroying acquisitions, suggested by substantially negative market reaction to the acquisition announcements. In a similar vein, Liu and Jiraporn (2010) suggest that significant stakeholders, such as bondholders, take CEO power into contracting consideration. Specifically, banks demand firms with powerful CEOs for significantly higher costs of debt in terms of bond yields. Firms with powerful CEOs also incur lower credit ratings, suggesting an unfavorable perception of CEO power from the perspective of debtholders. Adams et al. (2005) also explore the impact of CEO power on the volatility of firm performance. They argue that powerful CEOs are less likely to share power with other top executives who play an important advisory and monitoring role in corporate decision making, which lead to a higher likelihood of erroneous decisions from the powerful CEOs. Their empirical findings suggests a positive correlation between the volatility of firm performance and the degree of CEO power as the likelihood of erroneous corporate decisions increases. Collectively, these empirical evidence indicates that CEO power is a manifestation of agency problem and firms with powerful CEOs incur significant economic costs.

We depart from prior literature examining the economic consequence of CEO power by exploring how CEO power may impact a significant financial reporting decision: auditor selection. We specifically examine if firms with powerful CEOs are more likely to hire Big-four international auditors.

Our research is motivated by the competing motives grounded in the agency theory. Prior research suggests that due to incentive to protect their reputation and the tremendous litigation risk arising from audit failures, big-4 auditors provide better monitoring than non-big-4 auditors (Linda DeAngelo, 1981). Firms with powerful CEOs may be reluctant to hire big-4 auditors to improve the financial reporting transparency as powerful CEOs may have incentive to garble accounting information about their poor performance.

One the other hand, there is a countervailing incentive for powerful CEOs to improve accounting transparency by hiring big-4 auditors. In an agency conflict setting, insiders may want to hire high quality auditors as a signal of higher quality financial reporting so as to obtain favorable contracting terms, such as cost of equity (Joseph Fan and T.J. Wong 2005). Therefore, powerful CEOs would be more likely to hire big-4 auditors to lower the information asymmetry to reduce the financing costs. The above arguments render a tension that motivates our empirical pursuit.

Following Bebchuk et. al (2011), we use CEO pay slice as an empirical proxy of CEO power. The CEO pay slice (CPS), calculated as a ratio of total CEO compensation to the total compensation of the top-five executives, captures the relative importance of CEO within the $\mathrm{C}$-suite management. This empirical proxy of CEO dominance is tested and validated by its significant explanatory power to a rich set of corporate performance variables and other corporate outcomes, such as Tobin's q, accounting profitability, credit ratings and financing costs and is a widely accepted and used empirical proxy of CEO power (Bebchuk et. al 2011; Yixin Liu and Pornsit Jiraporn, 2010; Pornsit Jiraporn, Pandej Chintrakarn and Yixin Liu 2012).

We obtain the auditor information of the U.S. firms from the Audit Analytics database and financial information from Compustat. Our final sample includes 9,686 observations in total and spans between 1992 and 2011. Our empirical analysis suggests that powerful CEOs are more likely to hire high-quality auditors.

Our research makes several contributions to the literature in accounting and finance. First, we are related to the literature on CEO characteristics at a general level. Prior studies suggest CEO characteristics are associated with 


\section{Z. Liu et al /International Journal of Finance \& Banking Studies \\ Vol 4, No 4, 2015 ISSN: 2147-4486}

firm performance and firm behaviors, such as overconfidence and narcissism. Our evidence indicates that powerful CEOs who dominate corporate decisions in the C-suite groups have significant influence in corporate decisions. Second, it contributes to the understanding of the impact of CEO power on firm behaviors. Prior literature suggests that CEO power has substantial impact on firm performance and cost of debt (Bebchuk et. al 2011; Liu and Jiraporn, 2010). We extend this literature by examining the impact of CEO power on auditor selection behavior, which has never been explored before. Finally, our studies contribute to the literature of determinants to auditor switching. Prior literature has identified several significant determinants to auditor selection, such as firm size, financial reporting quality and corporate governance. Our study adds an important dimension to this literature by discovering that managerial characteristics may also impact the auditor selection decision.

The rest of this paper proceeds as follows. Section II discusses the sample construction and describes the variables. Section III discusses the empirical findings. Finally, Section IV presents the concluding remarks.

\section{Sample Selection and Research Design}

We obtain the auditor information of the U.S. firms from the Audit Analytics database for the years 2000-2011. We then merge with Compustat for firms' financial information and with ExecuComp for the information of executive compensation. We delete firms from the regulated and financial industry as these firms are under a different regulation environment. Additionally, we winsorize all continuous variables at the 1 percent and 99 percent levels to mitigate the potential outliers' effects. Our final sample includes 9,686 observations in total.

Prior literature has provided several factors affecting the auditor selection process. In this study, our focus is the effect of CEO power on auditor selection. Following Ho and Kang (2013), we perform the following auditor selection model using the probit maximum likelihood method:

$B I G N$

$$
\begin{gathered}
=\mathrm{b}_{0}+\mathrm{b}_{1} * P O W E R+\mathrm{b}_{2} * S I Z E+\mathrm{b}_{3} * D A+\mathrm{b}_{4} * B M+\mathrm{b}_{5} * R O A \\
+\mathrm{b}_{6} * C U R R+\mathrm{b}_{7} * S P+\mathrm{b}_{8} * N A S+\mathrm{b}_{9} * Y E A R+\mathrm{b}_{10} * I N D+\mathrm{e}_{\mathrm{t}}
\end{gathered}
$$

Where:

$B I G N=1$ if the firm chose a Big $\mathrm{N}$ auditor; and 0 otherwise;

POWER = CEO power measured by the CEO's compensation divided by the total compensation of the top five executives;

SIZE $\quad=$ Natural logarithm of total assets;

$D A \quad=\quad$ Total long-term debt divided by total assets;

$B M \quad=\quad$ Book-to-market ratio;

$R O A=$ Income before interest and taxes scaled by total assets;

CURR = Total current assets divided by total assets;

$S P \quad=1$ if the firm has a special item; and 0 otherwise;

$N A S=$ Total non-audit fees to total audit fees;

YEAR = Dummy variables of year; and

IND $\quad=$ Dummy variables of industry. 


\section{Z. Liu et al /International Journal of Finance \& Banking Studies \\ Vol 4, No 4, 2015 ISSN: 2147-4486}

The dependent variable $(B I G N)$ is the probability of a firm selecting one of the Big $\mathrm{N}$ auditors. The variable of interest is the CEO power (POWER). Following Bebchuk et al. (2011), we measure each executive's compensation as the sum of all forms of annual pay, including salary, bonus, and other annual pay, plus any restricted stock, stock options, long-term incentive payouts, and all other compensation. Then we use the percentage of the CEO compensation to the total compensation of the top five executives as the proxy of CEO power. ${ }^{1}$ Compare to the traditional proxy of CEO power (i.e. CEO is also the chair of the board), our pay slice measure captures the importance of the CEO in the top executive team as well as the ability of the CEO to negotiate their contract.

Following prior literature (Chaney et al. 2004; Jayne Godfrey and Jane Hamilton 2005; Joanna Ho and Fei Kang 2013), the control variables in our auditor selection model include measures of firm size, complexity, financial health, and auditor-client relationship. Firm size (SIZE) is measured by the natural logarithm of the firm's total asset. We expect a positive relationship between firms size and Big $\mathrm{N}$ auditor given that Big $\mathrm{N}$ auditors have more capability and resources to handle large clients. We also include the debt-asset ratio $(D A)$ and the book-to-market ratio $(B M)$ to capture the business risk of the client. Firms' profitability $(R O A)$ is measure by the earnings before interest and taxes scaled by total assets. Firms with low profitability may have high incentives to engage in earning management behavior and therefore may influence the auditor selection process. The percentage of current assets to total assets $(C U R R)$ as well as the special item $(S P)$ is included to indicate the complexity of the client. The percentage of non-audit fees to total fees $(N A S)$ is also included to proxy for the auditor-client relationship. Lastly, the year dummies and industry dummies are included to control the year and industry effects.

\section{Empirical Results}

\section{Univariate Results}

Table 1 presents the descriptive statistics of the variables in the auditor selection model. The mean of $B I G N$ is 0.955 , indicating that around 95 percent of firms in our sample is audited by a Big $\mathrm{N}$ auditor. This is consistent with the results in Joanna Ho and Fei Kang (2013). The average CEO power is 0.388 , similar to the mean of 0.357 in Bebchuk et al. (2011). The mean and median for the natural logarithm of total assets (SIZE) are very close (7.403 and 7.275, respectively), suggesting the measure of size is not skewed. The average long-term debt to total asset $(D A)$ and the book-to-market ratio $(B M)$ is 0.173 and 0.469 , respectively. Regarding the profitability of our sample firms, the mean of ROA is 0.052 , with the minimum of -5.779 and the maximum of 0.365 . In addition, the average current asset to total asset $(C U R R)$ is 0.471 . Around 75 percent of our sample firms report a special item and the average percentage of non-audit fees to total audit fees is 26 percent.

\footnotetext{
${ }^{1}$ Consistent with Bebchuk et al. (2011), we only include firm-years in which CEOs receive the full year compensation. This way avoid mechanically decreasing the CEO pay slice based on partial year payment.
} 


\section{Z. Liu et al /International Journal of Finance \& Banking Studies \\ Vol 4, No 4, 2015 ISSN: 2147-4486}

Table 1 : Descriptive Statistics for Variables in Auditor Selection Model $(\mathrm{N}=9,686)$

\begin{tabular}{|c|c|c|c|c|c|c|}
\hline \multicolumn{2}{|r|}{ Variable Name } & \multirow{2}{*}{$\begin{array}{l}\text { Mean } \\
0.955\end{array}$} & \multirow{2}{*}{$\begin{array}{l}\text { Standard } \\
\text { Deviation } \\
0.208\end{array}$} & \multirow{2}{*}{$\begin{array}{l}\text { Median } \\
1.000\end{array}$} & \multirow{2}{*}{$\begin{array}{l}\text { Minimum } \\
0.000\end{array}$} & \multirow{2}{*}{$\begin{array}{l}\text { Maximum } \\
1.000\end{array}$} \\
\hline BIGN & & & & & & \\
\hline POWER & & 0.388 & 0.112 & 0.393 & 0.062 & 0.703 \\
\hline SIZE & & 7.403 & 1.433 & 7.275 & 3.274 & 10.761 \\
\hline DA & & 0.173 & 0.171 & 0.149 & 0.000 & 1.490 \\
\hline $\mathrm{BM}$ & & 0.469 & 0.317 & 0.407 & -0.146 & 1.893 \\
\hline ROA & & 0.052 & 0.133 & 0.059 & -5.779 & 0.365 \\
\hline CURR & & 0.471 & 0.204 & 0.466 & 0.034 & 0.986 \\
\hline SP & & 0.754 & 0.430 & 1.000 & 0.000 & 1.000 \\
\hline NAS & & 0.266 & 0.216 & 0.211 & 0.000 & 0.812 \\
\hline$B I G N$ & \multirow{2}{*}{\multicolumn{6}{|c|}{$\begin{array}{l}=1 \text { if the firm chose a Big } \mathrm{N} \text { auditor; and } 0 \text { otherwise; } \\
=\quad \text { CEO power measured by the CEO's compensation divided by the total compensation of the top five } \\
\text { executives; }\end{array}$}} \\
\hline POWER & & & & & & \\
\hline SIZE & \multicolumn{6}{|c|}{$=$ Natural logarithm of total assets; } \\
\hline$D A$ & \multicolumn{6}{|c|}{$=$ Total long-term debt divided by total assets; } \\
\hline$B M$ & \multicolumn{6}{|c|}{$=$ Book-to-market ratio; } \\
\hline$R O A$ & \multicolumn{6}{|c|}{$=$ Income before interest and taxes scaled by total assets; } \\
\hline CURR & \multicolumn{6}{|c|}{$=$ Total current assets divided by total assets; } \\
\hline$S P$ & \multicolumn{6}{|c|}{$=\quad 1$ if the firm has a special item; and 0 otherwise; } \\
\hline$N A S$ & \multicolumn{6}{|c|}{$=$ Total non-audit fees scaled by total audit fees and non-audit fees; } \\
\hline$Y E A R$ & \multicolumn{6}{|c|}{$=$ Dummy variables of year; and } \\
\hline$I N D$ & \multicolumn{6}{|c|}{$=$ Dummy variables of industry. } \\
\hline
\end{tabular}

The Pearson (Spearman) correlations among the variables in the audit selection model are presented above (below) the diagonal in Table 2. The correlation between BIGN and POWER is positive and significant using both the Pearson (Corr. $=0.069$; p-value $<0.0001$ ) and the Spearman (Corr. $=0.0670$; p-value $<0.0001$ ) correlation methods, supporting the notion that powerful CEOs are more likely to select Big N auditors. Several correlations between the control variables are significant at five percent level, but none of them is higher than 0.500 . Therefore, it seems that multicollinearity is not an issue in our multivariate regression test. 
Z. Liu et al /International Journal of Finance \& Banking Studies

Vol 4, No 4, 2015 ISSN: 2147-4486

Table 2: Correlation Matrix among Variables in Auditor Selection Model $(\mathrm{N}=9,686)$

\begin{tabular}{|c|c|c|c|c|c|c|c|c|c|}
\hline & BIGN & POWER & SIZE & DA & BM & ROA & CURR & SP & NAS \\
\hline \multirow[t]{2}{*}{ BIGN } & 1.000 & 0.069 & 0.206 & 0.126 & -0.037 & -0.032 & -0.130 & 0.097 & 0.112 \\
\hline & & $<.0001$ & $<.0001$ & $<.0001$ & $<.0001$ & 0.002 & $<.0001$ & $<.0001$ & $<.0001$ \\
\hline \multirow[t]{2}{*}{ POWER } & 0.070 & 1.000 & 0.178 & 0.086 & -0.045 & 0.081 & -0.102 & 0.062 & -0.027 \\
\hline & $<.0001$ & & $<.0001$ & $<.0001$ & $<.0001$ & $<.0001$ & $<.0001$ & $<.0001$ & 0.008 \\
\hline \multirow[t]{2}{*}{ SIZE } & 0.211 & 0.223 & 1.000 & 0.241 & -0.053 & 0.046 & -0.384 & 0.209 & 0.028 \\
\hline & $<.0001$ & $<.0001$ & & $<.0001$ & $<.0001$ & $<.0001$ & $<.0001$ & $<.0001$ & 0.006 \\
\hline \multirow[t]{2}{*}{ DA } & 0.152 & 0.132 & 0.362 & 1.000 & -0.062 & -0.121 & -0.421 & 0.146 & 0.055 \\
\hline & $<.0001$ & $<.0001$ & $<.0001$ & & $<.0001$ & $<.0001$ & $<.0001$ & $<.0001$ & $<.0001$ \\
\hline \multirow[t]{2}{*}{ BM } & -0.035 & -0.057 & -0.058 & 0.013 & 1.000 & -0.220 & -0.082 & 0.089 & -0.066 \\
\hline & 0.001 & $<.0001$ & $<.0001$ & 0.216 & & $<.0001$ & $<.0001$ & $<.0001$ & $<.0001$ \\
\hline \multirow[t]{2}{*}{ ROA } & -0.042 & 0.074 & 0.015 & -0.257 & -0.468 & 1.000 & 0.054 & -0.142 & -0.065 \\
\hline & $<.0001$ & $<.0001$ & 0.135 & $<.0001$ & $<.0001$ & & $<.0001$ & $<.0001$ & $<.0001$ \\
\hline \multirow[t]{2}{*}{ CURR } & -0.129 & -0.105 & -0.393 & -0.495 & -0.094 & 0.147 & 1.000 & -0.106 & -0.020 \\
\hline & $<.0001$ & $<.0001$ & $<.0001$ & $<.0001$ & $<.0001$ & $<.0001$ & & $<.0001$ & 0.045 \\
\hline \multirow[t]{2}{*}{ SP } & 0.097 & 0.077 & 0.215 & 0.168 & 0.099 & -0.235 & -0.106 & 1.000 & -0.017 \\
\hline & $<.0001$ & $<.0001$ & $<.0001$ & $<.0001$ & $<.0001$ & $<.0001$ & $<.0001$ & & 0.103 \\
\hline \multirow[t]{2}{*}{ NAS } & 0.124 & -0.013 & 0.055 & 0.065 & -0.081 & -0.035 & -0.028 & -0.008 & 1.000 \\
\hline & $<.0001$ & 0.188 & $<.0001$ & $<.0001$ & $<.0001$ & 0.001 & 0.007 & 0.452 & \\
\hline
\end{tabular}

Pearson (Spearman) correlations is above (below) diagonal.

Variable definitions are in Table 1. 


\section{Multivariate Results}

Table 3 presents the multivariate results on the relationship between auditor selection and CEO power. The coefficient on CEO power (POWER) is positive and significant at one percent level (Coeff. $=0.804$; P-value $=0.001)$, indicating that firms with a high power CEO are more likely to select Big $\mathrm{N}$ auditors. The results suggest that powerful CEOs are more likely to decrease the information asymmetry by hiring high quality auditors, with the possible intent to signal a high quality financial reporting which lead to a more favorable contracting terms.

Table 3: Probit Regression Results on the Auditor Selection Model $(N=9,686)$

\begin{tabular}{lll} 
Variables & Coefficient & P-Value \\
\hline INTERCEPT & & \\
POWER & -1.229 & $<.0001$ \\
SIZE & 0.804 & 0.001 \\
DA & 0.371 & $<.0001$ \\
BM & 0.885 & $<.0001$ \\
ROA & -0.385 & $<.0001$ \\
CURR & -0.890 & 0.003 \\
SP & -0.641 & $<.0001$ \\
NAS & 0.176 & 0.002 \\
INDUSTRY & 0.919 & $<.0001$ \\
YEAR & Yes & \\
$\boldsymbol{N}$ & Yes & \\
$\boldsymbol{R}$-SQUARE & 9,686 & \\
Variable definitions are in Table 1. & 0.08 & \\
For control variables, results suggest that larger firms are more likely to hire Big N auditors. Additionally, firms with \\
higher long-term debts, a special item, as well as a higher non-audit fee percentage, also have higher probability to \\
hire Big N auditors. On the other hand, the book-to-market ratio, ROA, and current asset ratio are found to be \\
negatively related to the selection of a Big N auditor.
\end{tabular}

\section{Conclusion}

In this paper, we examine the impact of CEO power on auditor choice. Prior research on CEO power primarily focuses on the economic impact of CEO power, such as firm performance and firm valuation. There is no empirical evidence of how CEO power is related to specific managerial decisions. We are motivated by the competing financial reporting incentives arising from CEO power. One the one hand, powerful CEO may have incentive to choose auditors with lower audit quality to garble accounting information. On the other hand, powerful CEOs may be more likely to hire high-quality auditors to curry the favor of the outside stakeholders as those auditors provide assurance of financial reports. Our empirical finding suggests that powerful CEOs are more likely to hire high-quality auditors as a signal of superior financial reporting quality. Our research has implication for the research of how CEO traits impact economic outcome. Our research also contributes to the research of auditor choice.

\section{References}

Adams R.B, Almeida H \& Ferreira D. (2005). Powerful CEOs and their impact on corporate performance. Review of Financial Studies 18(4):1403-1432

Bebchuk, L., M. Cremers, \& Peyer, U. (2011). The CEO pay slice. Journal of Financial Economics 102, 199-221. 
Chaney, P. K., Jeter, D. C. \& Shivakumar, L. (2004). Self-Selection of Auditors and Audit Pricing in Private Firms. The Accounting Review, 79(1), 51-72.

DeAngelo, L. E. (1981). Auditor size and audit quality. Journal of Accounting and Economics 3: 183- 199.

Fan, J. P. H., \& Wong, T. J. (2005). Do external auditors perform a corporate governance role in emerging markets? Evidence from East Asia. Journal of Accounting Research, 43(1), 35-72.

Finkelstein S. (1992). Power in top management teams: Dimensions, measurement, and validation. Academy of Management Journal 35: 505-538.

Godfrey, J. M., \& Hamilton, J. (2005). The Impact of R\&D Intensity on Demand for Specialist Auditor Services. Contemporary Accounting Research, 22(1), 55-93.

Ho, J. L., \& Kang, F. (2013). Auditor Choice and Audit Fees in Family Firms: Evidence from the S\&P 1500. Auditing: A Journal of Practice \& Theory, 32(4), 71-93.

Jeffrey Pfeffer. (2010). Power: Why Some People Have It—And Others Don’t. Harper Collins Publishers.

Jiraporn, P, Chintrakarn, P., \& Liu, Y. (2012). Capital structure, CEO dominance, and corporate performance, Journal of Financial Services Research 42, 139-158.

Liu Y \& Jiraporn, P. (2010). The impact of CEO power on bond ratings and yields. Journal of Empiral Finance 17:744-762. 